\title{
HUBUNGAN MEROKOK DENGAN MELANOSIS PEROKOK DI RUMAH SAKIT GIGI DAN MULUT BAITURRAHMAH
}

\author{
Yegie Triza*, Dhona Afriza** \\ *Mahasiswa FKG Universitas Baiturrahmah Padang \\ ** Bagian Penyakit Mulut, FKG Universitas Baiturrahmah, Padang
}

\section{KATA KUNCI}

Merokok, Melanosis merokok, Pigmentasi

\begin{abstract}
ABSTRAK
World Health Organization telah menetapkan bahwa tanggal 31 Mei sebagai hari bebas tembakau sedunia. Hal ini menunjukan semakin meningkatnya perhatian dunia terhadap akibat negatif rokok bagi kesehatan dan kesejahteraan manusia. Merokok adalah membakar tembakau yang kemudian dihisap asapnya baik menggunakan rokok maupun pipa. Salah satu akibat negatif dari kebiasaan merokok yang terjadi di rongga mulut adalah melanosis merokok. Melanosis terjadi akibat pengendapan melanin dalam lapisan epithelium mukosa mulut. Gambaran klinis yang terlihat pada melanosis perokok menunjukan adanya bercak coklat difus yang berukuran beberapa sentimeter terdapat pada gingiva anterior mandibula dan mukosa mulut. Penelitian ini merupakan penelitian survei analitik yang menggunakan desain case control yang di lakukan di RSGM Baiturrahmah. Penelitian ini dilakukan pada sampel 80 orang yang diambil secara acak yang terdiri dari 40 pasien perokok dan 40 pasien tidak perokok sebagai pengontrol. Hasil penelitian didapatkan bahwa melanosis perokok lebih banyak ditemukan pada responden perokok dibandingkan responden tidak perokok
\end{abstract}

\section{PENDAHULUAN}

World Health Organization telah menetapkan bahwa tanggal 31 Mei sebagai hari bebas tembakau sedunia. Hal ini menunjukan semakin meningkatnya perhatian dunia terhadap akibat negatif rokok bagi kesehatan dan kesejahteraan manusia ${ }^{1}$.

Data WHO 2008, menyebutkan bahwa Indonesia mengkonsumsi tembakau (rokok) sebesar 225 miliar batang pertahun (65 juta perokok atau $28 \%$ perpenduduk) sehingga Indonesia menempati urutan ketiga di antara negara-negara dengan tingkat agregat perokok terbesar dunia setelah Cina (390 juta perokok atau $29 \%$ per penduduk) dan India
(144 juta perokok atau $12,5 \%$ per penduduk) ${ }^{2}$.

Prevalensi merokok meningkat cepat seiring dengan bertambahnya umur, disebabkan karena tingkat stres pada kelompok umur tersebut tinggi dan pada umumnya kaum pria lebih banyak mengkonsumsi rokok untuk menghilangkannya ${ }^{3}$.

Salah satu akibat dari kebiasaan merokok yang terjadi di mulut adalah melanosis merokok (smoker's melanosis) menunjukkan prevalensi sekitar $31 \%$ yang terdapat pada gingiva cekat mandibula bagian labial.

Melanosis rongga mulut terjadi akibat pengendapan melanin dalam lapisan sel basal 
pada lapisan epithelium mukosa mulut. Pigmentasi melanin pada membran mukosa mulut secara normal terlihat mengelilingi daerah mukosa ${ }^{4}$. Melanosis rongga mulut adalah suatu lesi yang bersifat reversibel, dapat hilang apabila menghentikan kebiasaan merokok $^{4,5,6}$.

Melanosis perokok yang terjadi pada golongan etnis kulit hitam maupun kulit putih, dapat meningkatkan pigmentasi yang berhubungan langsung dengan kebiasaan merokok (jumlah rokok yang dihisap setiap hari, jenis rokok yang dihisap, lama merokok dan cara seseorang menghisap rokok) dan pigmentasi gingiva meningkat sebanding dengan konsumsi tembakau. Adapun hipotesis yang didapat yaitu kemungkinan nikotin menstimulasi aktivitas melanosit dan rokok tembakau? ${ }^{7}$.

Gambaran klinis yang terlihat pada melanosis perokok menunjukkan adanya bercak coklat difus yang ukurannya beberapa sentimeter dan biasanya terdapat pada gingiva anterior mandibula dan mukosa pipi $^{4,8}$. Pada perokok pipa menunjukkan pigmentasi pada mukosa bukal. Sebagian perokok yang mengunakan rokok putih yang diletakkan pada kavitas mulut, akan menunjukan pigmentasi pada palatum keras $^{9,10,11}$. Lesi ini tidak mempunyai symptom, perubahan yang terjadi tidak menunjukan premalignat $^{4}$. Gigi pada melanosis perokok menunjukan warna coklat muda sampai coklat tua dan juga disertai dengan halitosis. Hal tersebut disebabkan oleh adanya perubahan aliran darah dan pengurangan pengeluaran ludah yang mengakibatkan rongga mulut menjadi kering dan lebih anaerob ${ }^{8}$. Melanosis perokok biasanya terjadi pada ras Kaukasian yang menunjukkan prevalensi $31 \%$ pada gingiva cekat $^{4,12}$.

Adapun mekanisme terjadinya melanosis dimulai dari kebiasaan seseorang merokok yang di dalam asap rokok tersebut terdapat komponen gas yaitu karbonmonoksida, amoniak, asam hidrosianat, nitrogen oksida dan formaldehid dan partikelnya berupa tar, indoor, karbarzol dan kresol serta zat-zat ini beracun yang mengiritasi dan menimbukan kanker (karsinogen $)^{13}$. Rokok dapat menstimulasi melanosit mukosa mulut dan menghasilkan melanin berlebihan sehingga terjadi pigmentasi coklat pada mukosa bukal dan gingiva yang dikenal dengan melanosis perokok $^{14}$.

Diagnosis dapat dibuat dengan menghubungkan sejarah merokok dengan presentasi klinis dan riwayat medis. Penyebab lain pigmentasi melanin, seperti trauma, neurofibromatosis, Sindrom peutzjengers, pigmentasi narkoba, gangguan endokrin, hemochromatosis, penyakit paru kronis, dan pigmentasi rasial harus disingkirkan ${ }^{15}$.

\section{METODE PENELITIAN}

Penelitian ini merupakan penelitian survei analitik yang menggunakan desain case control, digunakan untuk mengetahui 
perbandingan antara kebiasaan merokok dengan tidak merokok berdasarkan terjadinya melanosis merokok.

Populasi dalam penelitian ini adalah seluruh pasien laki-laki di Rumah Sakit Gigi dan Mulut Baiturrahmah Padang Sumatera Barat. Penelitian dilakukan pada bulan Januari sampai Februari 2012. Jumlah subjek penelitian adalah 80 orang yang terdiri dari, 40 perokok dan 40 tidak perokok yang diambil dari pasien Rumah Sakit Gigi dan Mulut Pendidikan Baiturrahmah Padang.

Subjek penelitian kemudian diberikan informed consent dan dilakukan pemeriksaan klinis rongga mulut dengan bantuan 2 kaca mulut dan dengan penerangan lampu senter. Selanjutnya subjek penelitian diwawancara mengenai kebiasaan merokok.

Dilakukan analisa bivariate untuk menguji apakah ada hubungan antara perokok dengan terjadinya melanosis perokok, data analisis dengan menggunakan uji statistik. Hasil analisa menunjukkan adanya hubungan yang bermakna apabila nilai $p$ kurang dari $0,005(\alpha$ $<0,005) .{ }^{20}$

\section{HASIL}

Setelah dilakukan wawancara dengan menggunakan kuesioner terhadap 80 respoden perokok dan tidak perokok, maka diperoleh hasil sebagai berikut :
Tabel 1. Persentase Responden Perokok Berdasarkan Merokok dan Tidak merokok

\begin{tabular}{|c|c|c|c|}
\hline No & Karakteristik & Jumlah & $\begin{array}{c}\text { Persentase } \\
(\mathbf{\%})\end{array}$ \\
\hline 1 & Merokok & 40 & 50.00 \\
\hline 2 & Tidak Merokok & 40 & 50.00 \\
\hline & Total & 80 & 100.00 \\
\hline
\end{tabular}

Berdasarkan tabel 1 dapat dilihat dari 80 responden terdapat 40 responden $(50.00 \%)$ yang mempunyai kebiasaan merokok dan 50 responden $(50.00 \%)$ tidak merokok.

Dalam penelitian ini responden tidak perokok merupakan kontrol untuk hasil penelitian terhadap terjadinya melanosis merokok. Untuk lebih jelasnya, hasil penilitian responden ada tidaknya melanosis perokok dapat dilihat sebagai berikut :

Tabel 2. Persentase Responden Tidak Perokok Berdasarkan Ada Tidaknya Melanosis

\begin{tabular}{|c|c|c|c|}
\hline No & Karakteristik & Jumlah & $\begin{array}{c}\text { Persentase } \\
(\mathbf{\%})\end{array}$ \\
\hline 1 & Melanosis & 5 & 12.50 \\
\hline 2 & Tidak Melanosis & 35 & 87.50 \\
\hline & Jumlah & 40 & 100.00 \\
\hline
\end{tabular}

Bedasarkan tabel 2 dapat dilihat dari 40 responden tidak merokok terdapat 5 responden (12.50\%) mengalami melanosis rongga mulut dan 35 responden $(87.50 \%)$ tidak mengalami melanosis rongga mulut. Dengan demikian, mayoritas responden tidak perokok tidak mengalami melanosis.

Tabel 3. Persentase Responden Tidak Perokok Berdasarkan Umur

\begin{tabular}{|c|c|c|c|}
\hline No & $\begin{array}{c}\text { Kelompok umur } \\
\text { ( Tahun ) }\end{array}$ & Jml & $\begin{array}{c}\text { Persentase } \\
(\boldsymbol{\%})\end{array}$ \\
\hline 1 & $18-25$ tahun & 36 & 90.00 \\
\hline 2 & $>25$ tahun & 4 & 10.00 \\
\hline & Total & 40 & 100.00 \\
\hline
\end{tabular}


Berdasarkan tabel 3 dapat dilihat bahwa dari 40 tidak perokok, 36 responden $(90.00 \%)$ adalah kelompok umur 18-25 tahun dan 4 responden (10.00\%) adalah kelompok umur $>25$ tahun. Dengan demikian, mayoritas responden adalah berusia 18-25 tahun.

Selanjutnya, hasil penelitian pada perokok dapat dilihat sebagai berikut:

Tabel 4. Persentase Responden Perokok Berdasarkan

\begin{tabular}{|c|c|c|c|}
\multicolumn{4}{|c|}{ Ada Tidaknya Melanosis Rongga Mulut. } \\
\hline No & Perokok & Jumlah & $\begin{array}{c}\text { Persentase } \\
(\mathbf{\%})\end{array}$ \\
\hline 1 & Melanosis & 26 & 65.00 \\
\hline 2 & Tidak Melanosis & 14 & 35.00 \\
\hline & Total & 40 & 100.00 \\
\hline
\end{tabular}

Berdasarkan tabel 4 dapat dilihat dari 40 responden perokok terdapat 26 responden $(65.00 \%)$ mengalami melanosis rongga mulut dan 14 responden $(35.00 \%)$ tidak mengalami melanosis rongga mulut. Dengan demikian, mayoritas responden perokok mengalami melanosis.

Tabel 5. Persentase Responden Perokok Berdasarkan Umur

\begin{tabular}{|c|c|c|c|}
\hline No & $\begin{array}{c}\text { Kelompok umur } \\
\text { (Tahun) }\end{array}$ & Jumlah & $\begin{array}{c}\text { Persentase } \\
(\mathbf{\%})\end{array}$ \\
\hline 1 & $18-25$ tahun & 30 & 75.00 \\
\hline 2 & $>25$ tahun & 10 & 25.00 \\
\hline & Total & 40 & 100.00 \\
\hline
\end{tabular}

Berdasarkan tabel 5 dapat dilihat bahwa dari 40 responden perokok, 30 responden (75.00\%) adalah kelompok umur 18-25 tahun dan 10 responden $(25.00 \%)$ adalah kelompok umur > 25 tahun. Dengan demikian, mayoritas responden adalah berusia 18-25 tahun.

Selanjutnya, hasil penelitian pada perokok dapat ditunjukkan berdasarkan :

\section{Usia Awal Merokok}

Tabel 6. Persentase Responden Perokok Berdasarkan Usia Awal Merokok

\begin{tabular}{|c|l|l|l|}
\hline No & $\begin{array}{l}\text { Usia Awal } \\
\text { Merokok }\end{array}$ & Jumlah & $\begin{array}{c}\text { Persentase } \\
(\mathbf{\%})\end{array}$ \\
\hline 1 & $<15$ tahun & 10 & 25.00 \\
\hline 2 & $15-18$ tahun & 23 & 27.50 \\
\hline 3 & $>18$ tahun & 7 & 17.50 \\
\hline & Total & 40 & 100.00 \\
\hline
\end{tabular}

Berdasarkan tabel 6 dapat dilihat bahwa dari 40 responden, 10 responden $(25.00 \%)$ usia awal merokok < 15 tahun, 23 responden (27.50\%) usia awal merokok antara 15-18 tahun dan 7 responden (17.50\%) usia awal merokok > 18 tahun. Dengan demikian, responden usia awal merokok paling tinggi pada kelompok 15-18 tahun.

\section{Jenis Rokok}

Tabel 7. Persentase Responden Perokok Berdasarkan Jenis Rokok

\begin{tabular}{|l|l|l|l|l|}
\hline No & $\begin{array}{l}\text { Jenis } \\
\text { Rokok }\end{array}$ & Jumlah & $\begin{array}{l}\text { Persent } \\
\text { ase } \\
(\%)\end{array}$ & $\begin{array}{l}\text { Melano } \\
\text { sis (\%) }\end{array}$ \\
\hline 1 & Kretek & 11 & 27.50 & 63.64 \\
\hline 2 & Putih & 18 & 45.00 & 50.00 \\
\hline 3 & Campura & 11 & 27.50 & 90.91 \\
\hline & Total & 40 & 100.00 & \\
\hline
\end{tabular}

Berdasarkan tabel 7 dapat dilihat bahwa dari 40 responden, 11 responden $(27.50 \%)$ merokok dengan jenis rokok kretek, 18 responden $(45.00 \%)$ merokok dengan jenis rokok putih dan 11 responden (27.50\%) 
merokok dengan jenis rokok campuran. Dengan demikian, jenis rokok yang paling banyak di konsumsi responden adalah rokok putih.

\section{Lama Merokok}

Tabel 8. Persentase Responden Perokok Berdasarkan Lama Merokok

\begin{tabular}{|c|c|c|c|c|}
\hline No & $\begin{array}{c}\text { Lama } \\
\text { Merokok }\end{array}$ & Jml & $\begin{array}{c}\text { Persentase } \\
(\mathbf{\%})\end{array}$ & $\begin{array}{c}\text { Melano } \\
\text { sis (\%) }\end{array}$ \\
\hline 1 & $<3$ tahun & 11 & 27.50 & 9.09 \\
\hline 2 & $3-5$ tahun & 9 & 22.50 & 66.67 \\
\hline 3 & $>5$ tahun & 20 & 50.00 & 95.00 \\
\hline & Total & 40 & 100.00 & \\
\hline
\end{tabular}

Berdasarkan tabel 8 dapat dilihat bahwa dari 40 responden, 11 responden $(27.50 \%)$ sudah merokok di bawah 3 tahun, 9 responden (22.50\%) sudah merokok antara 3-5 tahun dan 20 responden $(50.00 \%)$ sudah merokok di atas 5 tahun. Dengan demikian, sebagian responden sudah merokok diatas 5 tahun.

\section{Jumlah Rokok}

Tabel 9. Persentase Responden Merokok Berdasarkan Jumlah Rokok

\begin{tabular}{|c|c|c|c|c|}
\hline No & $\begin{array}{c}\text { Jumlah } \\
\text { Rokok }\end{array}$ & Jml & $\begin{array}{c}\text { Persentase } \\
(\mathbf{\%})\end{array}$ & $\begin{array}{c}\text { Melanosis } \\
(\mathbf{\%})\end{array}$ \\
\hline 1 & $1-4$ & 7 & 17.50 & 0.0 \\
\hline 2 & $5-14$ & 19 & 47.50 & 63.16 \\
\hline 3 & $>15$ & 14 & 35.00 & 100.00 \\
\hline & Total & 40 & 100.00 & \\
\hline
\end{tabular}

Berdasarkan tabel 9 dapat dilihat bahwa dari 40 responden, 7 responden $(17.50 \%)$ mengkonsumsi rokok antara 1-4 batang per hari, 19 responden $(47.50 \%)$ mengkonsumsi rokok antara 5-14 batang per hari dan 14 responden $(35.00 \%)$ mengkonsunsi rokok lebih dari 14 batang per hari. Dengan demikian, sebagian besar responden mengkonsumsi 5-14 batang per hari.

\section{Cara Menghisap Rokok}

Tabel 10. Persentase Responden Perokok Berdasarkan Cara Menghisap Rokok

\begin{tabular}{|c|c|c|c|c|}
\hline No & $\begin{array}{c}\text { Cara } \\
\text { Menghisap } \\
\text { Rokok }\end{array}$ & Jml & $\begin{array}{c}\text { Persentase } \\
(\mathbf{\%})\end{array}$ & $\begin{array}{c}\text { Melano } \\
\text { sis (\%) }\end{array}$ \\
\hline 1 & Paru Mulut & 14 & 35.00 & 35.71 \\
\hline 2 & Paru & 14 & 35.00 & 85.71 \\
\hline 3 & Paru Dalam & 12 & 30.00 & 75.00 \\
\hline & Total & 40 & 100.00 & \\
\hline
\end{tabular}

Berdasarkan tabel 10 dapat dilihat bahwa dari 40 responden, 14 responden $(35.00 \%)$ merokok melalui paru mulut, 14 responden (35.00\%) merokok melalui paru dan 12 responden $(30.00 \%)$ merokok melalui paru dalam. Dengan demikian, sebagian besar responden merokok melalui paru mulut dan paru.

Analisis yang dilakukan pada penelitian menggunakan analisis deskriptif dengan melihat tabulasi silang kebiasaan merokok dan tidak merokok terhadap terjadinya melanosis rongga mulut.

Tabel 11. Tabulasi Silang Antara Kebiasaan Perokok dan Tidak Perokok dengan Terjadinya

\begin{tabular}{|l|l|l|l|l|}
\multicolumn{1}{|c|}{ Melanosis } & Merokok & $\begin{array}{l}\text { Tidak } \\
\text { Merokok }\end{array}$ & $\begin{array}{l}\text { Ratio } \\
\mathbf{9 5 \%} \\
\text { confident } \\
\text { interval) }\end{array}$ & Sig-p \\
\hline Melanosis & $65.00 \%$ & $12.50 \%$ & & \\
\cline { 1 - 3 } $\begin{array}{l}\text { Tidak } \\
\text { Melanosis }\end{array}$ & $35.00 \%$ & $87.50 \%$ & $\begin{array}{l}13 \% \\
4.2-40.6\end{array}$ & \multirow{2}{*}{0.000} \\
\cline { 1 - 3 } P & $100 \%$ & $100 \%$ & & \\
\hline
\end{tabular}


Dari tabel 11 dapat dilihat bahwa dari 40 responden (100\%) yang merokok, 26 responden $(65.00 \%)$ yang mengalami melanosis rongga mulut dan 14 responden $(35.50 \%)$ tidak terjadi melanosis rongga mulut. Dari 40 responden (100\%) yang tidak merokok, 5 responden (12.50\%) yang mengalami melanosis rongga mulut dan 35 responden $(87.50 \%)$ tidak terjadi melanosis rongga mulut. Hal ini menunjukkan bahwa tingginya tingkat terjadinya melanosis pada perokok.

Hasil uji statistik menggunakan chisquare memperlihatkan bahwa nilai signifikansi $\mathrm{p}=$ 0.000 atau $<\operatorname{sig} \alpha(0.05)$. Dengan demikian, Ho ditolak atau $\mathrm{H}_{1}$ diterima sehingga dapat disimpulkan bahwa perokok berpengaruh signifikan terhadap insiden melanosis karena nilai sig-hitung chi-square $(0,000)<0.05$.

\section{PEMBAHASAN}

Dari penelitian diatas, perokok mempunyai resiko terjadinya melanosis adalah $65.00 \%$ dan tidak melanosis $35.00 \%$, sedangkan pada responden yang tidak merokok resiko terjadinya melanosis adalah $12.50 \%$ dan yang tidak melanosis $87,50 \%$ disini didapatkan bahwa orang yang merokok lebih banyak beresiko terjadinya melanosis dari pada orang yang tidak merokok, hal ini sesuai dengan literatur insiden terjadinya melanosis adalah $31 \% .{ }^{4}$ Yarger dan Melone juga menyatakan bahwa melanosis merokok yang terjadi pada etnis kulit putih maupun kulit hitam, dapat meningkatkan pigmentasi yang berhubungan langsung dengan kebiasaan merokok dan pigmentasi gingiva meningkat sebanding dengan konsumsi tembakau. ${ }^{4,7}$ Pada penelitian ini didapatkan bahwa resiko perokok dan tidak perokok yang dapat mengakibatkan terjadinya melanosis perokok adalah $13 \%$.

Dari penelitian ini terlihat dari 80 responden yang mengambil bagian dari penelitian ini, kelompok yang terbanyak merokok adalah usia di atas >20 tahun. Berdasarkan data WHO Indonesia, prevalensi merokok pada pria meningkat cepat seiring dengan bertambahnya umur.

\section{SIMPULAN}

Berdasarkan hasil analisis dan pembahasan yang telah dilakukan tentang hubungan kebiasaan merokok dengan terjadinya melanosis rongga mulut yang dilakukan terhadap 40 responden yang mempunyai kebiasaan merokok dan 40 responden yang tidak merokok, dapat disimpulakan bahwa :

1. Ada hubungan kebiasaan merokok terhadap terjadinya melanosis karena adanya peranan pigmentasi melanin yang diakumulasi oleh macam-macam bahan seperti nikotin yang terkandung dalam sebatang rokok.

2. Penelitian ini ditemukan bahwa melanosis perokok lebih banyak ditemukan pada responden perokok (65.00\%) dibandingkan responden yang tidak merokok (12.50\%). 


\section{SARAN}

Penelitian ini hanya menguraikan secara umum mengenai hubungan antara melanosis perokok dengan kebiasaan merokok pada perokok. Oleh karena itu diharapkan adanya penelitian lanjutan dengan sampel yang lebih besar, kalangan yang berbeda untuk melakukan evaluasi lebih lanjut.

\section{DAFTAR PUSTAKA}

1. Aditama TY. 1995. Proses Berhenti Merokok.Cermin Dunia Kedokteran ; 102 : 37-40.

2. Ech - Nusantara. 2009. 10 Negara Dengan Jumlah Perokok Terbesar Di Dunia. <http://nusantaranews.wordpress.com/2009/0 5/31/10-negara-jumlah perokok-terbesar-didunia/>.

3. Smet B. 1994. Psikologis Kesehatan. Semarang: PT Gramedia.

4. Johson, W \& Bain, CA. 2007, Tobacco and Oral Desiase. British Dental Journal; 189(4): 200-206.

5. Bauquot, J \& Schroeder, K. 2007, Oral Effects of Tobacco Abuse. Journal Of The America Dental Institute For Continuing Education; 43: 3-17.

6. Persatuan Dokter Gigi Indonesia. 2007. Bahaya Merokok. <http://www.pdgionline.com/V2/index.php2options=com_conte nt\&taks=view\&id=310\&itemid=1 7 mei 2010>.

7. Yarger, VB \& Malone, R. 2006, Melanin and Nicotine: A Review of Literatur. Nicotine and Tobacco Research ; 8 (4): 487-489.

8. Langlais, RP \& Miller, CS. 1998, Atlas Berwarna Kelainan Rongga Mulut yang Lazim. Alih Bahasa: Budi Susetyo. Jakarta: Hipokrates: 70.

9. Machuca, G, Rosales, I, Lacalle, JR, Machuca, C \& Bullon, P. 2000, Effect of Cigarette Smoking on Periodontal Status of Healthy Young Adults. J Periodontal ; 71(1): 8-73.

10. Syam AS, Cheung LK, Jin IJ, Corbet EF. 2003. The Effect of Tobacco Use On Oral Health. Hongkong Med J ; 9(4) : 271-277.
11. Carpenter WS. 2009. Smoker's Melanosis. < http://emedicine.medscape.com /article/1077501-overview $>$.

12. Prime. Smoking and Oral Health. Dental Practice. SOH; 1(3).

13. Anymous. 2008. Rokok dan Kesehatan Rongga Mulut. < http://www.pdgionline.com/v2/index.php?option=com_conten t\&task=view\&id=30Itemid=1 > .

14. Dewi D. 2005. Pengaruh Kebiasaan Merokok Terhadap Mukosa Mulut. Dentika J Dent; 10(2) :132-135.

15. Neville, BW, Damm, DD \& Bauquot, JE. 2004, Oral Maxillofacial Pathologi. Saunders : Philadhelphia: 228-229.

16. Scurlly, C. 2008. Oral And Maxillofacial Madicine. London : Philadhelphia: 109-118.

17. Fawzani, N \& Triratnawati, A. 2005, Terapi Berhenti Merokok ( Studi Kasus 3 Perokok Berat). Makula Kesehatan ; 9(1): 15-22.

18. Santoso SS. 1993. Perilaku Merokok yang Berkaitan dengan Kebiasaan Merokok. Cermin Dunia Kedokteran ; 84: 41-17.

19. Ruslan G. 1996. Efek Merokok terhadap Rongga Mulut. Jurnal Cermin Kedokteran; 113: 41-43.

20. Sastroasmoro S \& Ismael S. 2011, DasarDasar Metodologi Penelitian Klinis. Jakarta: Binarupa Aksara. 